Юлія ЖДАНОВИЧ, orcid.org/0000-0002-5611-4475 аспірант кафедри дизайну Київського наиіонального університету культури і мистеитв (Київ, Україна)1010bios1989@gmail.com

\title{
МІМЕЗИС І ПОЙЕСІС У ФОРМУВАННІ СІЛЬСЬКОГО ПРЕДМЕТНОГО СЕРЕДОВИЩА ХХ СТОЛІТТЯ НА СЛОВ'ЯНО-РОМАНСЬКОМУ ПОГРАНИЧЧІ УКРАЇНИ
}

\begin{abstract}
У даній статті проаналізована роль мімезису й пойесісу у формуванні сільського предметного середовища ХХ століття на слов'яно-романському пограниччі Украӥни. Встановлено, щчо мімезис та пойесіс - ие поняття, щзо динамічно розвиваються у контексті етнографічного розвитку етнічних прикордонних регіонів у різні культурно-історичні періоди. У ході формування сільського предметного середовища мешканці традиційної культури схильні до наслідування (мімезису). Водночас входження інноваційності в повсякденний уклад залишає місие творчості і нововведенням (пойесісу). Наскільки тісно вони переплетені - залежить не лише від регіону чи населеного пункту, а й від кожної сільської родини - української, румунської чи змішаної. Виявлено, шьо для нашої країні не були характерні політичні пограниччя, оскільки кордони в середині ХХ століття прокладалися без урахуванням етнічного фактора, оскільки перевага віддавалася ідеологічним і безпековим засадам. Проаналізовано загальні тренди прагнення до наслідування й творчості в українському пограниччі на прикладі українсько-румунського (Буковина Закарпаття) та украӥнсько-молдавського (Поділля, Одещчина, Бессарабія) погранич. Така специфіка в етнічній ідентифікації мешканців слов'янсько-романського прикордоння: населення українськорумунського пограниччя характеризується православним віросповіданням, з огляду на щзо етнічну належність спільноти оптимальним чином можливо проаналізувати на підставі мови - відповідно української та румунської. Мімезисом зазначеної ситуації є те, щуо мова традиційно відрізняла украӥнців від молдаван і румун (натомість релігія об'єднувала ичі етноси). Пойесіс, очевидно, полягає в тому, щзо одним із найміцніших чинників національної приналежності в иъьому регіоні є предметне середовище, щзо формувалося під впливом як географії (Карпати, Лicocmen, Степ близькість до моря), так і розуміння кожним етносом духовного розвитку й економічних факторів. Обгрунтовано, щзо зображені й розглянуті явища на украӥнському пограниччі з Румунією й Молдовою значною мірою відображають тренди, притаманні більшості подібних територій Центрально-Східної Свропи, а також виражають достатню диверсифікованість та неоднозначність еволюиї етнічних спільнот в умовах пограниччя, тим більше коли йдеться про різні за історичним минулим народи -зокрема, слов'янські й романські.

Ключові слова: мімезис, пойесіс, сільське предметне середовище, слов'яно-романське пограничя, Україна, Румунія, Молдова, етнографія.
\end{abstract}

Yuliia ZHDANOVYCH, orcid.org/0000-0002-5611-4475

Postgraduate Student at the Department of Design Kiev National University of Culture and Arts (Kyiv,Ukraine)1010bios1989@gmail.com

\section{MIMESIS AND POIESIS IN THE FORMATION OF THE RURAL OBJECT ENVIRONMENT OF THE XX CENTURY ON THE SLAVIC-ROMANIC BORDER OF UKRAINE}

This article analyzes the role of mimesis and poiesis in the formation of the rural object environment of the twentieth century on the Slavic-Romanic border of Ukraine. It has been established that mimesis and poiesis are the concepts dynamically developing in the context of ethnographic development of ethnic border regions in different cultural and historical periods. During the formation of the rural object environment the inhabitants of traditional culture tend to imitate (mimesis). At the same time, the entry of innovativeness into everyday life leaves room for creativity and innovation (poiesis). How closely they are intertwined depends not only on the region or locality, but also on each rural family - Ukrainian, Romanian or mixed. It has been revealed that our country was not characterized by political borders, since the borders in the middle of the twentieth century were drawn without taking into account the ethnic factor, as the preference was given to ideological interests and security principles. The general trends of aspiration to imitation and creativity in the Ukrainian frontier were analyzed on the example of Ukrainian-Romanian (Bukovina Transcarpathia) and Ukrainian-Moldavian (Podolia, Odessa, Bessarabia) frontiers. Such specificity in ethnic identification of Slavic- 
Romanian borderland inhabitants: the population of Ukrainian-Romanian borderland is characterized by Orthodox Christianity, given that ethnicity of the community can be analyzed optimally on the basis of language - Ukrainian and Romanian respectively. The mimesis of this situation is that speech traditionally distinguished Ukrainian from Moldavians and Romanians (instead, religion united these ethnoses). Poiesis obviously is that one of the strongest factors of national belonging in the region subject environment, which was formed under the influence of both geography (Carpathians, forest-steppe, Steppe proximity to the sea) and each ethnos'understanding of spiritual development and economic factors. It has been substantiated that the depicted and examined phenomena in the Ukrainian borderland with Romania and Moldova largely reflect the trends inherent in most similar territories of Central-Eastern Europe and express sufficient diversification and ambiguity of the evolution of ethnic communities in the borderland conditions, especially when it comes to peoples with different historical backgrounds - particularly Slavic and Romanesque.

Key words: mimesis, poiesis, rural object environment, Slavic-Romanic borderland, Ukraine, Romania, Moldova, ethnography.

Актуальність теми. Мімезис і пойесіс у формуванні сільського предметного середовища ХХ століття на слов'яно-романському пограниччі України є актуальним і поки малодослідженим питанням для наукового розгляду. Вказане зокрема пояснюється тим, що вказані наукові концепти ще не використовувалися саме у розрізі етнографії та краєзнавства.

Уявлення про предметне середовище як про друге створення природи, сам ідеал наближення до природності, відтворення природи, зрозумілої й повтореної у їі найбільш істотних проявах, пізнаної в найголовніших законах передбачає особливе ставлення до реальності. Це ставлення неминуче проявляється в такому типі сприйняття предметного середовища, яке ми називаємо теоретичним. Його найбільш істотна риса - аналіз замість «боротьби 3 природою», відсутність потреби у насильницьких методах перетворення природи. Часом здається, що прогрес теоретичного ставлення до реальності - завоювання сучасності. Це не зовсім так, оскільки досить згадати те значне число проєктів із насильницького підпорядкування природи не завжди розумній волі людини. Питання тут не в технічних можливостей здійснення проєктів, а у самому принципі їх появи.

Сьогодні дослідники перебувають у досить складній і неоднозначній ситуації. 3 одного боку, цілком очевидно, що весь історичний розвиток предметного середовища, у тому числі в його етнографічному вимірі, найтіснішим чином пов'язаний із проблемою мімезису. 3 іншого боку, сама ця проблема представляється майже зрозумілою. Ототожнення ролі предметного середовища із деталізованим відтворенням природи для професійного культурознавства, а також етнографії лишається анахронізмом.

У цьому контексті продуктивним $є$ звернення до дефініції мімезису і пойесісу як явищ, які, 3 одного боку, вельми активно присутні у культурному, насамперед традиційному й класичному контекстах, а з іншого - не повною мірою відпо- відають творчій суті предметного середовища, оскільки представляють собою досить архаїчне явище, яке майже не використовується для оцінки сучасної етнографії й відповідної культурнопобутової практики.

Зв'язок даної теми із важливими науковими завданнями інших дисциплін. Означена тема перебуває на перехресті кількох наук етнографії, краєзнавства, етнології, культурології, історії філософії.

Стан дослідження теми. Тематика оцінки етнографічних особливостей окремих регіонів України через призму бачення, філософії й культурології не є новою для вітчизняної науки. Водночас проблематика власне мімезису й пойесісу стала предметом нечисленних культурологічних досліджень таких науковців нашої країни, як Ф. Штейнбук, Ю. Юхимик, В. Дубініна тощо. Що стосується оцінки предметного середовища на слов'яно-романському пограниччі України, то це питання стало об'єктом вивчення таких дослідників, як Н. Стрельчук, М. Чучко, Б. Боднарюк, I. Воротняк, а також М. Герман, які комплексно і скрупульозно досліджували етнокультурний та етнополітичний ландшафт прикордонних регіонів України, Молдови та Румунії в історичній ретроспективі та у контексті сучасного стану. Лишається тільки розглянути рівень наслідування i креативності у матеріальному побуті порубіжжя слов'янського світу 3 романським на території нашої країни, а саме її південно-західної частини.

Виклад основного матеріалу. У буквальному перекладі $з$ давньогрецької мови «мімезис» i «пойесіс» означають «наслідування» і «творчість». Два ці поняття мають досить інноваційне значення у нашому повсякденному слововживанні, до них постійно звертається мистецтвознавство й теорія мистецтва, а також фахівці з інших гуманітарних дисциплін, зокрема стосовно предметного середовища. Саме їх поширеність робить їх досить розмитими в інших побутових значеннях. Цим власне пояснюється полемічність бага- 
тьох наукових досліджень, присвячених історії формування уявлень про предметне середовище. Наука прагне виокремити повсякденні уявлення й відновити актуальний теоретичний зміст власних понять. Без звертання до історії така реконструкція неможлива, але й історичне вивчення теорії розвитку предметного середовища, у т.ч. в етнографічному контексті досить ускладнене.

Крізь призму сучасних уявлень багато ідей минулої культури сприймаються досить видозмінено, і щоб відновити їх справжній зміст, необхідно зрозуміти характер асоціацій, що привносяться нами й нашою епохою і які міняють до невпізнанності думку минулих періодів історії культури й предметного середовища.

Реконструкція справжнього значення наукових понять, зокрема понять естетики повсякденного побуту, та розгляд їх в історичному розвитку сьогодні особливо важливі. Тим більше коли мова йде про мімезис, який часто сприймається на рівні повсякденних значень слова «наслідування», але не в його справжньому початковому змісті.

Сучасна наука повинна прагнути подолати розрив між тим значенням, яке надавалося концепції «наслідування» у минулі періоди історії, i тим, що наразі мається на увазі під наслідуванням. Необхідно виходити із припущення, що теорії «наслідування» були набагато більш змістовні в минулому, ніж це здається на перший погляд. I сучасний науковець повинен намагатися реконструювати їх дійсний зміст, а не ставитися до них як до наївних оман.

Новоєвропейська теорія творчості, що пізніше оформилася у постмодерний період в історію культурології, у т.ч. в іiі етно-вимірі, народжувалася не в результаті відмови від античної концепції мімезису, а у формі їі переосмислення. Саме в межах традиційного для Ренесансу положення про «наслідування природі» народжувалися нові ідеї про взаємовідношення людини й незалежної від нього реальності. Ці ідеї необхідно розглядати в контексті появи нової для європейської культури критики антропоцентризму й розвитку уявлення про природну стихію, що «мстить» людині за і1і втручання, що принципово відрізняють новоєвропейський погляд на місце людини у світі від античних проєктів перебудови предметного середовища. Розвиток концепції «мистецтва усередині природи» і еволюція середньовічних інтерпретацій наслідування природі «за способом дії» здобувають у сучасній культурі характер обгрунтування наслідування функціональним закономірностям i внутрішній логіці устрою природи (переважно в архітектурній теоріi).
Говорячи про роль «мімезису» і «пойесісу» у формуванні предметного середовища в українській культурі,зокрема 3 огляду на етнографічні особливості різних регіонів нашої країни, слід вказати, що особлива роль тут належить розвитку уявлень про діяльний початок у природі й продуктивної діяльності людини. Історична еволюція уявлення про «природу, що творить», і Бога-Майстра пов'язана з особливостями переносу уявлень про ремісничу, технічну й художню практику людини на реальність і виникнення концепції Бога-Художника. Якщо колись діяльність творення розумілася за аналогією 3 діяльністю ремісника, то українська традиція вже ототожнює Бога 3 архітектором, живописцем або скульптором. Божественне мистецтво - це першомодель, мистецтво людське - пї повторення, але не просте, не поверхневе, не буквальне, а здатне проникнути в суть.

Формування предметного середовища в українській культурі а їі краєзнавчому вимірі найбільш яскраво виявилося в появі нового відношення до майстерності виконання. При цьому, на відміну від теорії літературної творчості й риторики, що мали тривалу традицію оцінки якості виконання i докладно трактують питання техніки, образотворче мистецтво сприймалося (наскільки можна судити за описами, що дійшли до нас) сюжетно. Особливе ставлення до майстерності художника у контексті розвитку предметного середовища в українській культурі та етнографії пов'язане 3 формуванням нової художньої еліти й зміною ii самооцінки. Професійне художнє середовище визначає в цей період особливості естетичної оцінки творів мистецтва, які набагато тісніше, чим у минулі епохи, пов'язані зі знанням ремісничої сторони художньої творчості. Образний лад твору більше не розпадається на мімезис-техне й мімезис-фантазію, а до технічної досконалості виконання перестають ставиться як до більш низького порівняно із сюжетикою рівня.

У контексті розуміння предметного середовища України, звичайно, якщо намагатися розглянути феномен мімезису у історичному значенні, то 3 вказаною інтерпретацією важко, імовірно, було б не погодитися, оскільки за цими переконаннями мімезис зображує кореляцію між екстралінгвістичним реальним станом справ та художніми засобами представлення цієї реальності, у т.ч. в ході конструювання повсякденного побуту. Водночас найбільш вагомою постаттю у процесі мімезису $є$ людська особистість, однак не індивідум загалом й тим більше не мешканець країни як абстрактне поняття. Натомість мова йде про людину як творця предметного середовища, 
а зокрема - про предметно-побутовий світ людського помешкання як засіб розвитку й функціонування особи як у матеріальній, так і в духовно-культурній і релігійній сферах. Загалом, для позбавлення традиційних підходів до етнокультурології цю думку сформувати слід ще інакше: предметне середовище розуміється нами як певний комплексний феномен, який, зокрема, не розділяється на матеріальну та духовну складову, а лише через свою універсальну та специфічну природу спроможний з результатами формувати як перше, так і друге (Штейнбук, 2009). Історія етнографії й культури свідчить, що у процесі становлення мистецтво дедалі більш чітко стверджує себе як галузь, де знаходить відображення не тільки певні зразки формальної досконалості чи оригінальності матеріального, предметного світу, але і як сегмент творчого осмислення у ній багатоаспектності виявів буття (аспект пойесісу), що однаково важливі і для людини і для соціуму (певної етнічної спільноти). Поступово смислове трактування терміну «мімезис» охопило, зрештою, практично усі сегменти і сфери природного, предметного буття - у т.ч. у вияві звичаїв і традицій (Юхимик, 2013: 5).

Паралельно із цим обгрунтовано з'являється поняття «пойесіс» - тобто творчість; у цьому етно-культурному контексті нового сенсу набуло значення «закон»: до його онтологічного значення - «закони природи» - додалося і правове «людське встановлення» (ці дефініції воно зберігає і до сих пір) (Дубініна, 2018: 31-36).

Як наголошують дослідники у сфері етнокультурології, сприймання людською особистістю предметного середовища має системний тип, $\mathrm{i}$, як будь-яка інша система, людина намагається досягнути зрозумілої рівноваги не лише між окремими компонентами цього процесу - інтелектуальними, емоційними, вольовими, але й між архаїкою та інноваційністю, застосуванням мімезису чи пойесісу (Юхимик, 2013: 5).

Художньо-міметична чи, навпаки, творча пойесістична умовність не обмежена лише відмінностями між матеріалами реальних об'єктів та художніх творів, що виникають у ході конструювання предметного середовища, а сягає більш глибоких сутностей розвитку мистецтва у контексті етнографічного трактування.

Соціальна видозмінюваність українського соціуму розпочалася водночас зі змінами статусу адміністративних меж у державах Центральної Свропи після динамічних змін початку XX століття. Соціальна динаміка охопила пограничні регіони, в т.ч. українсько-романське прикор- доння. Істотно розширився потенціал соціальних суб'єктів пограничних регіонів, в XX століття ознаменувалося більшою динамікою міжгрупових контактів. До цього варто додати більш розвинену міждержавну співпрацю у соціально-економічній і політичній сферах, а також посилення фактору міжетнічної взаємодії. Для суб'єктів територій слов'янсько-романського пограниччя усвідомлення індивідуальної й групової ідентичності виявилося дуже актуальним. Тим більше ці тренди актуалізувалися у середині XX століття. Різні міметичні види (предметно-тілесний, процесуальний, динамічний, психоемоційний, ідейний та смисловий), якими етнографи навчилося результативно оперувати протягом тривалої історії розвитку предметного середовища у слов'янськороманському прикордонні, націлені на різну міру співпадіння із зовнішньо- чи внутрішньо формальними характерними рисами об'єктивних характеристик предметного середовища, що зумовлено активізацію різних асоціативних комплексів. Виражально-смислові фактори предметного середовища стають «вмикачами» смислів, націлених або на наслідування, або на творчість, оскільки предметний стан має розвиватися від пасивно-очікувального формату дотворчої активності тобто пойесісу. Саме від якісного формування початкової художньо-міметичної форми залежить остаточний результат, рівень розвитку культури і мистецтва в кожному компоненті природного середовища. Усе це ще більш важливо для прикордонних регіонів України де відбувається дифузія різних культур і традицій.

Висновки. Тією мірою, в якій українське суспільство починає усе вище оцінювати професійне ремесло, принципово змінюється характер оцінки творів мистецтва. На місце суто риторичних міркувань про шляхетність мистецтва й право живопису або скульптури бути віднесеними до числа «вільних мистецтв» приходить справді нова оцінка цінності майстерності. Нова самосвідомість художників, що стали справжньою елітою, сформувала не тільки особливе ставлення до професійних критеріїв оцінки творів, але й нову професійну етику. В Україні поки ще рано говорити про протиставлення мистецтва й «ремісництва», але вже можна знайти критику суто ремісничої експлуатації власних умінь, коли талант продається за гроші й стає засобом, а не метою. Мімезис та пойесіс - поняття, що динамічно розвиваються у контексті етнографічного розвитку етнічних прикордонних регіонів у різні культурно-історичні періоди. Очевидно, що в ході формування сільського предметного середовища 
мешканці традиційної культури схильні до наслідування (мімезису). Водночас входження інноваційності в повсякденний уклад залишає місце творчості і нововведенням (пойесісу). Наскільки тісно вони переплетені - залежить не лише від регіону чи населеного пункту, а й від кожної сільської родини - української, румунської чи змішаної. Для нашої країні не були характерні політичні пограниччя, оскільки кордони в середині XX століття прокладалися без урахуванням етнічного фактора, оскільки перевага віддавалася ідеологічним і без пековим засадам. Для більшості з регіонів українсько-романського прикордоння був характерним змішаний тип матеріальної культури. До того ж слід додати дисперсних тип розселення представників національних спільнот серед титульного етносу, як, наприклад, в Одеській та Чернівецький областях (Україна) або у Південній Буковині (Румунія). Проаналізовано загальні тренди прагнення до наслідування й творчості в українському пограниччі на прикладі українсько-румунського (Буковина Закарпаття) та українсько-молдавського (Поділля, Одещина, Бессарабія) погранич. Виявлено таку специфіку в етнічній ідентифікації мешканців слов'янськороманського прикордоння: населення українськорумунського пограниччя характеризується православним віросповіданням, $з$ огляду на що етнічну належність спільноти оптимальним чином можливо проаналізувати на підставі мови - відповідно, української та румунської. Мімезисом зазначеної ситуації є те, що мова традиційно відрізняла українців від молдаван і румун (натомість релігія об'єднувала ці етноси). Пойесіс, очевидно, полягає в тому, що одним із найміцніших чинників національної приналежності в цьому регіоні $\epsilon$ предметне середовище, що формувалося під впливом як географії (Карпати, Лісостеп, Степ близькість до моря), так і розуміння кожним етносом духовного розвитку й економічних факторів. Обгрунтовано, що зображені й розглянуті явища на українському пограниччі з Румунією й Молдовою значною мірою відображають тренди, притаманні більшості подібних територій ЦентральноСхідної Європи, а також виражають достатню диверсифікованість та неоднозначність еволюції етнічних спільнот в умовах пограниччя, тим більше коли йдеться про різні за історичним минулим народи - зокрема, слов'янські й романські.

Перспективи даного дослідження. На нашу думку, достатньо перспективним у контексті вивчення проблематики цієї теми $є$ розгляд таких питань: оцінка термінологічної коректності застосування дефініцій мімезису і пойесісу до етнографічної науки і досліджень у цілому; розгляд становлення етнокультурної специфіки слов'янороманського пограниччя в попередні періоди (орієнтовно 3 Київської Русі); компаративний аналіз загальних рис сільського предметного середовища на слов'янсько-романському й інших етнічних пограниччях нашої держави (слов'яноугорському, українсько-польському тощо).

\section{СПИСОК ВИКОРИСТАНИХ ДЖЕРЕЛ}

1. Дубініна В. Герменевтичний проект В. Дільтея. Вісник Львівського університету. Серія філософсько-політологічні студіi. 2018. Вип. 16. С. 31-36.

2. Дубова О. Б. Мимесис и пойэсис: Античная концепция «подражания» и зарождение европейской теории художественного творчества. Москва : Памятники исторической мысли, 2001. $271 \mathrm{c.}$

3. Дяченко Ю. Г. Інтернаціональне та національне в сучасному дизайні. Вісн. Харк. держ. акад. дизайну $і$ мистеитв. 2002. № 6. С. 248-250.

4. Никитина Н. Н. Мимесис и пойэсис в эстетике Аристотеля. Вестник МГУ. 1978. № 1. С. 75-85.

5. Перець О. О. Гуманізація сучасного предметно-просторового середовища українських регіонів художніми знаками традиційної естетики. Вісн. Харк. держ. акад. дизайну і мистецтв. Мистецттвознавство. Архітектура. Харків, 2006. № 5. С. 43-56.

6. Подорога В. Мимесис. Материалы по аналитической антропологии литературы. Москва : Культурная революция; Логос; Logos-altera, 2006. 688 с.

7. Пономарьов А. П. Українська минувшина: ілюстрований етнографічний довідник. Київ : Либідь, 1993. 256 с.

8. Рендюк Т. Г. Національні меншини в українсько-румунських відносинах: історичний досвід та сучасні проблеми (1990-2007 роки) : автореф. дис. ... д-ра іст. наук : 07.00.02 ; Дип. акад. України. Київ, 2012. 38 с.

9. Сільські території українсько-румунського прикордоння: соціально-економічний розвиток / А. О. Максименко та ін. ; редкол.: В. В. Борщевський, Д.-М. Войцилаш. Львів : НАН України, Держ. установа «Ін-т регіон. дослідж. ім. М. І. Долішнього НАН України», Румун. акад. наук, Ін-т аграр. економіки, 2015. 123 с.

10. Стрельчук Н. В., Чучко М.К., Боднарюк Б.М., Воротняк І.Д., Герман М.Г. та ін. Етнокультурний та етнополітичний ландшафт прикордонних регіонів України, Молдови та Румунії: іст. ретроспектива і сучас. стан. Чернівці : Технодрук, 2018. 255 с.

11. Штейнбук Ф. Тілесність - мімезис - аналіз (Тілесно-міметичний метод аналізу художніх творів): монографія. Київ : Знання України, 2009. 215 с.

12. Щербаківський В. Орнаментація української хати = L'ornementation de la maison rustique ukrainien. Pим, 1980. $46 \mathrm{c}$ 
13. Юхимик Ю. В. Асоціативність як база художнього мімезису. Вісник Національної академї керівних кадрів культури і мистещтв. 2013. № 3. С. 3-7.

14. Юхимик Ю. В. Мімезис: естетико-мистецтвознавчий аналіз засадничого принципу класичного мистецтва : монографія. Київ, 2005. 177 с.

\section{REFERENCES}

1. Dubinina V. Hermenevtychnyi proekt V. Dilteia [V. Dilthey's hermeneutic project]. Visnyk Lvivskoho universytetu. Seriia filosofsko-politolohichni studii. 2018. Vol. 16. pp. 31-36 [in Ukrainian]

2. Dubova O. B. Mimesis i pojjesis: Antichnaja koncepcija "podrazhanija" i zarozhdenie evropejskoj teorii hudozhestvennogo tvorchestva [Mimesis and Poiesis: The Ancient Concept of "Imitation" and the Birth of the European Theory of Artistic Creativity]. Moscow : Pamjatniki istoricheskoj mysli, 2001. 271 p. [in Russian].

3. Diachenko Yu. H. Internatsionalne ta natsionalne v suchasnomu dyzaini [International and national in modern design]. Visn. Khark. derzh. akad. dyzainu i mystetstv. 2002. № 6. pp. 248-250. [in Ukrainian]

4. Nikitina N.N. Mimesis i pojjesis v jestetike Aristotelja [Mimesis and Poiesis in Aristotle's Aesthetics] Vestnik MGU. 1978. № 1. pp. 75-85. [in Russian].

5. Perets O. O. Humanizatsiia suchasnoho predmetno-prostorovoho seredovyshcha ukrainskykh rehioniv khudozhnimy znakamy tradytsiinoi estetyky [Humanization of the modern subject-spatial environment of Ukrainian regions by artistic signs of traditional aesthetics]. Visn. Khark. derzh. akad. dyzainu i mystetstv. Mystetstvoznavstvo. Arkhitektura. 2006 . № 5. pp. 43-56. [in Ukrainian]

6. Podoroga V. Mimesis. Materialy po analiticheskoj antropologii literatury [Mimesis. Materials on the analytical anthropology of literature. Moscow: Kul'turnaja revoljucija; Logos; Logos-altera, 2006. 688 p. [in Russian].

7. Ponomarov A. P. Ukrainska mynuvshyna: iliustrovanyi etnohrafichnyi dovidnyk [Ukrainian past: illustrated ethnographic guide] / A. P. Ponomarov, L. F. Artiukh, T. Betekhtina ta in. Kyiv : Lybid, 1993. 256 p. [in Ukrainian]

8. Rendiuk T. H. Natsionalni menshyny v ukrainsko-rumunskykh vidnosynakh: istorychnyi dosvid ta suchasni problemy (1990-2007 roky) : avtoref. dys. ... d-ra ist. nauk : 07.00.02 [National minorities in Ukrainian-Romanian relations: historical experience and modern problems (1990-2007): author's ref. dis. ... Dr. East. Science: 07.00.02] ; Dyp. akad. Ukrainy. Kyiv, 2012. 38 p. [in Ukrainian]

9. Silski terytorii ukrainsko-rumunskoho prykordonnia: sotsialno-ekonomichnyi rozvytok [Rural areas of the UkrainianRomanian border: socio-economic development] / A. O. Maksymenko ta in.; redkol.: V. V. Borshchevskyi, D.-M. Voitsylash. Lviv : NAN Ukrainy, Derzh. ustanova «In-t rehion. doslidzh. im. M. I. Dolishnoho NAN Ukrainy», Rumun. akad. nauk, In-t ahrar. ekonomiky, 2015. 123 p. [in Ukrainian]

10. Strelchuk N. V., Chuchko M.K., Bodnariuk B.M., Vorotniak I.D., Herman M.H. ta in. Etnokulturnyi ta etnopolitychnyi landshaft prykordonnykh rehioniv Ukrainy, Moldovy ta Rumunii: ist. retrospektyva i suchas. stan. [Ethnocultural and ethnopolitical landscape of the border regions of Ukraine, Moldova and Romania: East. retrospective and modern. state]. Chernivtsi : Tekhnodruk, 2018. 255 p. [in Ukrainian]

11. Shteinbuk F. Tilesnist - mimezys - analiz (Tilesno-mimetychnyi metod analizu khudozhnikh tvoriv): Monohrafiia [Corporeality - mimesis - analysis (Body-mimetic method of analysis of works of art): monograph]. Kyiv : Znannia Ukrainy, 2009. 215 p. [in Ukrainian]

12. Shcherbakivskyi V. Ornamentatsiia ukrainskoi khaty =Lornementation de la maison rustique ukrainien [Ornamentation of the Ukrainian house = L'ornementation de la ruison house ukrainien]. Rym 1980. 46 p. [in Ukrainian]

13. Iukhymyk Yu. V. Asotsiatyvnist yak baza khudozhnoho mimezysu [Associativity as the basis of artistic mimesis]. Visnyk Natsionalnoi akademii kerivnykh kadriv kultury i mystetstv. 2013. № 3. pp. 3-7. [in Ukrainian]

14. Iukhymyk Yu. V. Mimezys: estetyko-mystetstvoznavchyi analiz zasadnychoho pryntsypu klasychnoho mystetstva : monohrafiia [Mimesis: aesthetic and art analysis of the basic principle of classical art: a monograph] . Kyiv, 2005.177 p. [in Ukrainian] 